9. Krusteva E. Effect of digoxin on experimental adrenaline-induced hyperglycemia and insulin-induced hypoglycemia. Folia Med (Plovdiv) 1992; 34: 14-6.

10. Bagrov YY, Manusova NB, Egorova IA et al. Marinobufagenin, an endogenous inhibitor of alpha-1 $\mathrm{Na} / \mathrm{K}$-ATPase, is a novel factor in pathogenesis of diabetes mellitus. Dokl Biol Sci 2005; 404 : 333-7.

11. Riganti C, Campia I, Kopecka J et al. Pleiotropic effects of cardioactive glycosides. Curr Med Chem 2011; 18: 872-85
12. The Digitalis Investigation Group. The effect of digoxin on mortality and morbidity in patients with heart failure. N Engl J Med 1997; 336: 525-33.

13. Ahmed A, Aban IB, Vaccarino V et al. A propensitymatched study of the effect of diabetes on the natural history of heart failure: variations by sex and age. Heart 2007; 93: 1584-90.

14. MacDonald MR, Petrie MC, Hawkins NM et al. Diabetes, left ventricular systolic dysfunction, and chronic heart failure. Eur Heart J 2008. 29. $1224-40$.
15. Preiss D Zetterstrand S. McMurray JJV et al. Predictors of development of diabetes in patients with chronic heart failure in the Candesartan in Heart Failure Assessment of Reduction in Mortality and Morbidity (CHARM) program. Diabetes Care 2009: 32: $915-20$

Mottatt 28.9. 2011, første revisjon innsendt 29.11. 2011, godkjent 2.2. 2012. Medisinsk redaktør Jon Amund Kyte.

\title{
Kommentar
}

\section{Digitalis og diabetes}

Digitalis har vært i bruk i medisinen i over 200 år, og litteraturen er omfattende. Søk i PubMed 27.2. 2012 med søkeordet «digitalis» ga over 12000 artikler. Til tross for lang tradisjon er mange spørsmål omkring stoffet ikke blitt avklart før ganske nylig. Det har to viktige bruksområder: hjertesvikt og atrieflimmer. Ikke før med den store DIG-studien fra 1997 (Digitalis Investigation Group) (1) ble det avklart at digitalis (digoksin) virkelig hadde en gunstig virkning ved hjertesvikt. En lærdom fra denne studien var at serumkonsentrasjonen burde være lavere enn det som var vanlig tidligere (2). Referanseområdet for både digitoksin og digoksin ble redusert.

I den foreliggende kasuistikken viser forfatterne at en pasient fikk betydelig stigning i nivåene av både $\mathrm{HbA}_{1 \mathrm{c}}$ og glukose etter oppstart av behandling med digitalis (digitoksin). Det har tidligere vært noen få rapporter om forverret diabetes med digoksin (3). Dersom det virkelig er en sammenheng mellom digitalis og forverret diabetes, er det svært underlig at dette ikke er blitt oppdaget tidligere, noe forfatterne også påpeker. Mulige forklaringer kan være at utslagene er mindre enn i dette tilfellet hos de fleste eller at diabetes er såpass vanlig hos dem som får digitalis at man ikke legger merke til forverring eller noen få ekstra tilfeller. Noe sikkert svar får vi trolig aldri. En prospektiv studie for å studere diabetes hos pasienter som får digitalis, ville være svært vanskelig å få finansiert. Man kunne kanskje få bedre kunn- skap ved å se på pasienter fra de store blodtrykks- og hjertesviktstudiene som fikk digitalis. For å få det til må man trolig ha adgang til originaldata.

Forfatterne anbefaler at pasienter med kjent diabetes skal følges nøye med $\mathrm{HbA}_{1 \mathrm{c}}{ }^{-}$ og glukosemålinger etter oppstart av digitalis. Jeg synes ikke grunnlaget for en slik anbefaling er godt nok og tror pasientene kan klare seg med vanlig diabeteskontroll.

I Norge var det i 2010 om lag 24000 personer som fikk utlevert digitoksin fra apotek og vel 1000 som fikk digoksin. Bruken av digitoksin er en norsk tradisjon, i de fleste andre land brukes digoksin. Det er flere fordeler med digitoksin, og jeg er fristet til å si at Norge har rett og verden tar feil. Men det hjelper dessverre ikke når digitoksin nå er avregistrert her i landet og vi må gå over til digoksin i løpet av 2012 og 2013. I samarbeid med kardiologer og kliniske farmakologer har Legemiddelverket laget retningslinjer for overgangen (4). Dessverre er det allerede meldt et dødsfall på grunn av overdosering av digoksin i forbindelse med medikamentskifte. Digitoksin og digoksin er begge legemidler med smalt terapeutisk vindu, og jevnlig kontroll av serumkonsentrasjonen er nødvendig for å unngå både overdosering og underdosering.

Observante klinikere som beskriver uvanlige hendelser i kasuistikker kan skape oppmerksomhet og få andre forskere på banen. Den mest berømte kasuistikken i historien er antakelig beskrivelsen av misdannelser hos barn av mødre som hadde bruk thalidomid (5).

Kanskje kan norske klinikere bidra til å løse gåten: Får man diabetes av digitalis?

Steinar Madsen

steinar.madsen@legemiddelverket.no

Statens legemiddelverk

Steinar Madsen (f. 1956) er spesialist i indremedisin og hjertesykdommer. Han er medisinsk fagdirektør ved Statens legemiddelverk og arbeider også i deltidsstilling som privatpraktiserende spesialist.

Forfatter har fylt ut ICMJE-skjemaet og oppgir ingen interessekonflikter.

Litteratur

1. The Digitalis Investigation Group. The effect of digoxin on mortality and morbidity in patients with heart failure. N Engl J Med 1997; 336: 525-33.

2. Madsen S, Holene E. Lavere digitalisdosering ved hjertesvikt. Tidsskr Nor Laegeforen 2007; 127 : 1053-4.

3. Spigset O, Mjörndal T. Increased glucose intolerance related to digoxin treatment in patients with type 2 diabetes mellitus. J Intern Med 1999; 246: 419-22.

4. Statens legemiddelverk. Overgang fra digitoksin til digoksin hos voksne. www.legemiddelverket.no/ templates/InterPage__83376.aspx (27.2.2012).

5. McBride WG. Thalidomide and congenital abnormalities. Lancet 1961; 278: 1358.

Mottatt 27.2. 2012 og godkjent 15.3. 2012. Medisinsk redaktør Jon Amund Kyte. 